\title{
RETROVERSION, INTROVERSION, EXTRAVERSION: THREE ASPECTS OF AFRICAN ANTHROPOLOGY
}

David Pratten

Africa is more important to anthropology than anthropology is to Africa.

(Barnard 2001: 163).

Africa, as Barnard states, has provided anthropology with 'unparalleled' case material on almost every aspect of social life. Over its long history of engagement with the discipline Africa has arguably contributed more than any other region to the anthropological study of familiar topics such as witchcraft, ritual symbolism, descent theory, and the politics and law in 'small-scale' societies (163). But we may ask, with others, whether this regional significance is still justified (Southall 1983; Guyer 2004). Given developments within African Studies and anthropology itself over the past quarter century, along with the articulation of a range of critical voices directed at Africanist anthropology, does Africa retain its important place within anthropology? How well has the field escaped the dilemma that Africa presents 'classic' ethnographic examples in both the exemplary and timeless senses of the term? How has Africa extended its contributed to anthropology beyond its 'classic cases' Azande witchcraft and sorcery, Barotse and Tiv judicial processes, Nuer and Tallensi lineage structure, Maasai age grades and Ndembu initiation?

Anthropology's agenda was shaped by challenges raised in African research - 
an agenda which was consolidated during the colonial period and which expanded with the social and political upheavals which coincided with the end of colonialism on the continent. Social anthropology therefore was the most established discipline in the study of sub-Saharan Africa before the independence period of the 1960s (Bates et al. 1993). As a direct result of this colonial history, however, anthropology has become the most controversial of all the disciplines through which sub-Saharan Africa has been studied. The status of the discipline has been called into question more critically in Africa than in perhaps any other regional context.

Compromised by its political complicities during the colonial era, and by its representations of African societies as functionally integrated, bounded and timeless, the voices critical of anthropology's 'invention of Africa' have been varied and persistent. In response to these post-colonial critiques, and broader post-modernist trends within the discipline, I argue that Africanist anthropology has adopted three aspects - retroversion, introversion, and extraversion. In the first section on its retrovert mode, I discuss how the anthropology of Africa emerges as a strong critique of its own intellectual heritage, realized in a flurry of analyses of the history of the field. And, in the second section, I demonstrate how Africanist anthropology has deployed its introversion to turn itself 'inside out' and how, in Marcus and Fischer's sense, anthropology in Africa has become an important 'cultural critique' (Marcus \& Fischer 1999: xvi). In relation to issues of development, the environment, and identity we can see that Africanist ethnographies have embraced Herzfeld's view of anthropology 'as a model for critical engagement with the world, rather than a distanced and magisterial explanation of the world' (Herzfeld 2001: x). The critiques of received wisdoms about Africa have arguably become 'new classics' within 
'critical anthropology'.

These shifts in the discipline, of course, are not tied simply to trends within the academy, but also to social, economic and political experience in Africa itself. No other region has undergone the length and intensity of turbulence that Africa has experienced since Independence. And in the period under review, broadly the past twenty-five years, Africa has experienced the most profound upheavals: the 1984 Ethiopian famine, the HIV/AIDS epidemic, the Rwandan genocide, civil wars on the Guinea Coast, structural adjustment programmes, and the end the Cold War and Apartheid. Underscoring this history are volatile economic trajectories. The impetus towards extraversion of the contemporary anthropology reviewed in the third section has been to interpret the effects of these profound shifts on African societies, and on beliefs and youth in particular. In these contexts, as Guyer states, the challenge for the anthropology of sub-Saharan Africa has been to engage with 'the radical configuration of religious, economic and political life in a contingent relationship to global religions, global markets and global political dynamics' (1999: 34).

\section{Retroversion}

Recent scholarship within Africanist anthropology has had a retroverted, backward looking perspective and has been as concerned with the discipline's colonial legacy as at any time since the independence era. The debate concerning the relationship between anthropology and colonialism has regularly revisited earlier critiques of European ethnocentrism (Mafeje 1971; Magubane 1971; Asad 1973; Owusu 1978). Mudimbe's $(1985,1988)$ interrogation of the power of anthropological constructions of Africa, for example, situates the critique within the discipline's use of categories 
and conceptual systems which depend on a Western epistemological order that he calls a 'colonizing structure'. Anthropology's way of knowing and representing Africa, he states is based on a set of paradigmatic oppositions:

traditional versus modern; oral versus written and printed; agrarian and customary communities versus urban and industrialized civilization; subsistence economies versus highly productive economies.

(Mudimbe 1988: 4)

Underpinning the emergence of the anthropological representation of Africa, Mudimbe states, is an implicit assumption of evolution from the former paradigms to the latter in this dichotomizing system.

Recognition of the influential legacy of these colonial ideologies has given rise to a debate over African anthropology's future (Magubane \& Faris 1985; Keita 1989; Rigby 1996; Mafeje 1998a, 2001). Indeed, in claiming that it has been caught between these colonial reifications and paralysing post-modernist self-reflections, Mafeje has condemned the discipline to an 'entropic death' (Apter 1999: 589), and insists that the post-modern era is a 'post-anthropological era' (2001: 66). Anthropology has been shunned on the continent, Mafeje argues, because it is not able to adapt to objects of study beyond those for which it was designed in the colonial period, and that unlike other social sciences ' ... anthropology as a discipline is founded on alterity which historically has issued into racism' (Mafeje 1998b: 101). While Mudimbe's critique powerfully establishes important limits on the practice of Africanist anthropology, we may echo Apter's observation that our understanding of 
the colonial encounter itself is nevertheless deepened when anthropology examines its own history (1999: 592).

Indeed, retroversion and introspection have combined in a 'flood' of reviews of the history of the discipline which serve to draw a line under the "phase in which anthropology and colonial rule were part of the same formation' (Pels 1997: 177). This historiography has primarily concerned itself with theoretical periodization. Overarching histories of the discipline in Africa during the colonial period are also narrated in Goody's (1995) The Expansive Moment and Kuklick's (1991) The Savage Within. The most comprehensive retrospective has been provided in Falk Moore's Anthropology and Africa (Moore 1994), ${ }^{1}$ which contrasts a first wave of anthropology during the colonial period, concerned to describe, understand, and compare 'traditional' societies in isolated and holistic fashion, with subsequent concern for 'changing' Africa, which took account of the impact of the cash economy, urbanization and wage labour. The net effect of these works has been to move the debate beyond generalized accounts - of anthropology as the reflection of colonial interests - and towards the more specific, contingent historical contexts of politics and place in the production of anthropology. Ordering Africa (Tilley \& Gordon 2007), for instance, revisits the stereotypical view of theoretically homogenous national schools of colonial anthropology by emphasising the transnational character of networks and institutions which comprised it, the debate and tensions over objectives and methods, the engagement with social change and the role of intermediaries (missionaries, administrator-ethnographers, assistants, and translators) in the production of

\footnotetext{
${ }^{1}$ The publication of this overview sparked further debate over the representation of African scholarship within the discipline (Mafeje 1997, 1998b).
} 
anthropological knowledge.

This reflection on African anthropology's past has also taken a regional focus. In their varied perspectives on the post-modernist literary critique of anthropology, contributors to Localizing Strategies (Fardon 1990) addressed the way in which research institutes divided and defined areas of study and characteristic regional research themes. This connection into the present, from an analysis of the history of anthropology in Africa's past, has also been addressed in ethnographic attempts to 'revisit the classics', and in attempts to shape regional ethnographic traditions through re-study or reinterpretation. Across the continent therefore anthropologists have returned to the ethnographic record of the colonial period in order to confront the 'colonizing structure' and to contest the tradition-modernity binary and to contextualize the opposition between subsistence, kinship, and traditional coherence, on the one side, and cash and the market, on the other.

In East Africa, for instance, Parkin (1990) highlights the thematic tradition of the study of states, descent and age-organisation in Kenya and Uganda, while James identified an 'investigative' mode of analysis common to Sudan and Ethiopia based on 'practical confrontation with the geography, economy, vernacular languages and patterns of authority' and typified by the work of Evans-Pritchard (James 1990: 131). An ethnography which re-encounters this classic ethnographic tradition, and propels its story towards the present, is Hutchinson's (1996) Nuer Dilemmas. Building upon Evans-Pritchard's field studies of the Nuer carried out during the 1930s Hutchinson sets out to shatter the illusion that 'Nuer culture and social life are somehow above history and beyond change' (1996: 21). 'No longer the isolated, independent, cattle- 
minded warriors immortalized by Evans-Pritchard' (22), Hutchinson's ethnography provides a counterpoint to his image of a balanced social harmony. Her historical and dynamic account of the Nuer's entanglements with conflict, cash and Christianity in Southern Sudan traces the shifting moral economy, premised on blood, cattle and food, from the end of colonial rule to the civil wars of the 1970s and 1980s. The commodification of livestock and labour in Nuer society, Hutchinson shows, heralds the reversal of the cultural logic of 'cattle over blood'. Social relations marked by the movement of cattle, have declined over the generations with political, legal and ritual consequences for managing and imagining marriage, divorce and death.

West African ethnographic traditions, Tonkin (1990) argues, emphasise the combination of an 'aspiration to coverage', the bounded unit of study and the centrality of descent. Structural-functionalism failed to survive decolonization as the field diversified into the study of state formation, economic development, gender and religion, and, as Hart (1985) notes, historical and Marxist approaches emerged to fill this theoretical gap. These established frameworks of West African ethnographic tradition have been challenged more recently on the grounds of their underlying Eurocentric formulations of personhood, agency and social relations. Piot's (1999) Remotely Global, for example, is a study of the Kabre of northern Togo which, while it is not a re-study, nevertheless provides a critique of the British descent theorists of the West African Volta basin, Fortes, Goody and Tait, and the French Marxist critique of Meillassoux and Terray. Piot follows two paths. First his work provides an ethnographic counterpoint to one of the key concepts of the regional ethnographic record. He argues that Fortes' conception of the lineage as a 'corporate', bounded, property-owning unit was based on a Eurocentric conception of an individualistic 
society and that the Kabre practice of friendship and exchange relations (ikpanture) shows that a relational ethos is also at work between groups. Second, Piot seeks to show how societies of the West African Sahel are not 'pristine spaces unaffected by history' and illustrates that Kabre culture has been constituted by mobility in its engagement with the slave trade, colonial labour, and post-colonial politics.

The history of the anthropology of south-central Africa, and the anthropologists of the Manchester School working at the Rhodes-Livingstone Institute, ${ }^{2}$ has become a productive area of study in its own right highlighting its colonial context and disciplinary legacy. In stressing the social brokerage role of the intermediaries, the research assistants and interpreters who worked with the anthropologists of the Rhodes-Livingstone Institute, Schumaker examines the ‘Africanization’ of anthropological knowledge production (Schumaker 2001). Africanizing anthropology is an 'anthropology of the anthropologists' which shows how fieldwork was subject to colonial circumstances, and hence situates the Institute's contribution to the discipline in the context of personal and political networks and everyday practices. Other analyses emphasise the empirical, theoretical and methodological innovations the 'school' produced in the analysis of social change during the 1950s and 60s in what is now Zambia, Zimbabwe and Malawi (Werbner 1984, 1990). In the context of social problems arising from industrialization and labour migration on the Copperbelt and elsewhere, these innovations focused on how to analyse the interaction and articulation of systems of social relations and values (or 'culture contact') between 'traditional rural subsistence production' and 'modern urban industrial production' (Werbner 1990: 156). The methodological innovations of

\footnotetext{
${ }^{2}$ Now the Institute for Social and Economic Research, University of Zambia.
} 
the case method, situational analysis and network theory developed by Gluckman and his colleagues were designed to move the ethnographic focus from the normative to actual practice and to capture the social as processual and situational. As a result, Evens and Hendelman (2006) argue that the extended case bore the seeds of another way of looking at the social altogether and anticipated practice theory.

Ferguson's (1999) study of the social effects of the decline of the Zambian mining sector in Expectations of Modernity argues that the researchers at the Rhodes Livingstone Institute (particularly its first Director Godfrey Wilson) were complicit in a 'modernization plot'. Their analysis of social change, he states, contrasted two ideological stereotypes, the 'migrant labouring tribesman versus permanently urbanized townsman', and a linear modernizing vision of 'a settled, permanent urban class of Africans' (Ferguson 1999: 34) which was not borne out in the complex historical patterns of mobility between rural and urban areas. The plot unravelled with declining commodity prices in the 1970s, and in his analysis of mine-workers' strategies for straddling the urban-rural connection Ferguson brings the analysis into the present in his anthropology of 'broken lives and shattered expectations'. 3

Turning further south, Kuper (1999) has identified a stream of contributions to the history of South African anthropology which have traced the contrasting trajectories of the Afrikaans-speaking Volkekunde and the English-speaking social anthropology in parallel to the historical association of the discipline with reactionary

${ }^{3}$ Other perspectives on Zambian society which revisit the post-colonial impact of the copper mining industry include (Moore \& Vaughan 1994; Crehan 1997; Hansen 1991; Hansen 2000). 
social forces of apartheid and with liberal and radical opposition (Sharp 1981; Gordon 1990; Gordon \& Spiegel 1993; Hammond-Tooke 1997). As Volkekunde (ethnology) 'captured' the discourse on ethnicity and cultural difference, so neoMarxist anthropological theorizing provided a new 'emblem of opposition' to apartheid and an impulse to 'document, expose, and challenge the social contradictions and political-cultural myths' of south and southern Africa (Gordon \& Spiegel 1993: 92). Wilmsen's (1989) Land filled with flies is a key example of this approach and takes its theoretical lead from Wolf(1982) in questioning the anthropological representation of the San-speaking peoples of southern Africa as a living laboratory of 'hunter-gatherers' and as historically remote from economic and social processes. Inextricably linked to the logics of colonial capitalism, Wilmsen argues that the 'Bushman/San' are not a timeless given entity but the end point of an historical process of dispossession from a cattle-herding economy, dislocation from the surrounding economies, and relegation to an underclass during the colonial era. ${ }^{4}$

The debate over culture and context in South African anthropology is also inflected in urban research. In his study of the city of East London, Bank's (2011) Home Spaces, Street Styles revisits the locus classicus of South African urban anthropology and the debate prompted by the publication of the Mayer's (1961) Townsmen or Tribesmen. Echoing the Copperbelt debate over the persistence of traditional rural identities amongst urban migrants, the East London controversy was

\footnotetext{
${ }^{4}$ The critical alternative emphasises how !Kung San have maintained an old but adaptable way of life based on hunter-gatherer modes of production (Lee \& Guenther 1993). Barnard (2007) points to the ways in which the image and portrayal of the Bushmen changes with generations of anthropological theory.
} 
inflected by the racial politics of the South African academy. Mayer's formulation of patterns of urban adaptation insisted that they were shaped by a fundamental cultural distinction, the Red/School divide, in the rural Xhosa countryside of the Eastern Cape. For Mayer this pointed to the resistance of the Red-migrants to the cultural influences of modern town life, but for his critics, including Mafeje (1971) and Magubane (1973), it was a form of cultural essentialism to assert that some migrants remained 'tribal' in outlook. Following Ferguson's conception of loose performative cultural styles rather than fixed impermeable identities, Bank's re-study concludes that the Red style is no longer influential in the township, and that we may best understand the complex lived space of the post-apartheid township through the lens of 'fractured urbanism' (2011: 241).

\section{Introversion}

As we have seen, Africanist anthropologists have, in recent decades, turned the gaze on themselves in revisiting classic ethnographies and ethnographic traditions. In turning itself 'inside out' it has become a 'science of self-examination'. The apparent involution of this process belies the important ethical commitment it makes in reflecting on the politics of knowledge production, and in contesting the "colonizing structure' of tradition versus modernity. Yet, it has gone further still. In an introverted mode questioning the implicit assumptions of their own disciplinary canon, Africanist anthropologists have also applied this critical gaze to contemporary African 'problems' and the conventional wisdoms that surround such issues as the environment, development, refugees and ethnicity. In this section I review key examples of the ways in which the anthropology of Africa has interrogated the production of authoritative 'scientific' accounts of Africa that have shaped policy and 
intervention. These Africanist cases are important exemplars and form part of a wider trend within the discipline in which ' $[\mathrm{T}]$ he destabilizing of foundational knowledges in many arenas of instrumental practice (the law, the sciences, political economy) continues to proceed apace ...' (Marcus \& Fischer 1999: xix).

Building on Richards' (1985) observation that farmers' knowledge was dismissed or ignored in colonial policy-making, the recent anthropology of agricultural and environmental change in Africa, typified by Fairhead and Leach's (1996) Misreading the African landscape and Moore and Vaughan's (1994) Cutting down trees, has been characterized by a mistrust of established, received wisdoms. Received wisdom about environmental change in Africa is captured in images of overgrazing and desertification based on neo-Malthusian assumptions that there is a fixed natural resource base (its 'carrying capacity') which will be exhausted by an expanding population. This received wisdom informs national and global policy, but recent anthropological approaches illustrate that, '... the same landscape changes can be perceived and valued in different ways by different groups; what is "degraded or degrading" for some may for other be merely transformed or even improved' (Leach \& Mearns 1996: 12).

In Misreading the African landscape Fairhead and Leach examine colonial conceptions of the Kissidougou forest in Guinea which were shaped by the belief that prior to French arrivals the landscape had been covered in pristine forest, and that its subsequent history was one of regression and loss under pressure from African farmers. Preconceived opinions of the rural farmer as 'environmental destroyer', common among today's foreign experts and urban-based state functionaries, they 
argue, is based on the, '[r]acialist, pejorative views of African farming and forestry practices [which] came to dominate Guinée's colonial administrations' (114-15). Their investigation into the history and local experience of forested areas surrounding village settlements (so-called 'forest islands'), reverses the received wisdom and shows how this ecological feature is not a relic in a deforested savannah, but a product, a growth of the social and agricultural management of the environment by the local population (121).

A parallel case, further illustrating the historical failings of expert knowledge in African rural economies, is provided by Moore and Vaughan's (1994) Cutting Down Trees. Revisiting Richards's (1939) classic Land, Labour and Diet they ask how Bemba shifting cultivation practices known as citemene were understood and represented by colonial experts in what is now northern Zambia. Ecologists of the period decried the environmental harm caused by the cutting and burning of trees to enrich soils for millet cultivation, while Richards had highlighted the effects on women when the male labour responsible for citemene migrated to the Copperbelt. The misconception arose, to which Richards contributed, that citemene agriculture and the lack of male labour had caused chronic under-nutrition throughout the region. In presenting a complex set of interwoven household strategies Moore and Vaughan's ethnography also inverts assumptions and shows how citemene was not the exclusive mode of agricultural production for Bemba farmers, and that women's, not men's labour was crucial.

The findings in these cases were prompted by the Foucauldian imperative to excavate the relationship between 'scientific' orthodoxy and the interests of the 
dominant authority; or as he put it, to uncover how power ' ... produces domains of knowledge and rituals of truth' (Foucault 1977: 194). The implications of the 'misreading' of farming and forestry for policy also apply to the wider project of post-war planning - 'development'. The scope of 'development' has served to 'reconfigure the political and institutional landscape of the social sciences' (Ferguson 1997), and a foundational text in the critical anthropology of development is an African exemplar. Ferguson's (1990) The Anti-Politics Machine provides an extended case study of an internationally funded development project in the highlands of Lesotho. In triangulating fieldwork between villagers, developers and the state, and in analysing the textual representation of Lesotho as a 'less developed country', Ferguson provides a model for the discursive unpicking of important categories in African social and political life.

The study makes three important contributions. First, in the manner of Apthorpe, Escobar, Sachs and others, Ferguson demonstrates the powerful effects of 'development discourse'. He argues that 'development' institutions generate their own form of language or discourse about Lesotho which simplifies and de-politicizes the divergent and complex contexts of poverty. Second, Ferguson demonstrates how this external expertise misreads the Basotho moral economy in relation to the exchange value of livestock. In an analysis of what he calls the 'bovine mystique', Ferguson explains that the project failed to commercialize livestock husbandry because cattle formed a unique category of property and source of prestige not convertible with cash. Third, and in a most innovative analytical move, Ferguson demonstrates that development projects, with an overtly apolitical agenda, nevertheless facilitated the political task of expanding state power in the guise of a 
technical mission. In this case a decentralization initiative comprising an improved road-link with the capital and a new district administration the project brought a stronger military and administrative state presence in a traditional opposition stronghold. It is in this light that Ferguson refers to the development project as an 'anti-politics machine', 'depoliticizing everything it touches, everywhere whisking political realities out of sight, all the while performing, almost unnoticed, its own preeminently political operation of expanding bureaucratic state power' (xv).

Like 'development', the category of 'refugees' is another object of knowledge and control which denotes an aberration of conventional categories and an objectified subject to 'therapeutic intervention'. Malkki's (1995) Purity and Exile examines the meaning of refugee status in a case study of Burundians who were displaced to Tanzania in the early 1970s. With the 'national order of things' taken for granted and the relationship between people and place naturalized in our conceptions of identity Malkki argues that the bodies and minds of refugees, of the displaced and deterritorialized, come to be seen as polluting, or even dangerous. Malkki further shows that the refugee camp nurtured an elaborate self-conscious historicity in which Hutu refugees challenged the classification of themselves in a 'mythico-history' which reified and heroized their national identity. By contrast to 'town' refugees in Kigoma, who apparently lost this 'moral history' to the 'shifting strategies of invisibility', the narrative constructions of essentialized national typologies of 'camp' refugees comprised a moral community and contained prescriptions for conduct based on the boundaries between self and other, Hutu and Tutsi, and good and evil (54). Ethnic, national and cultural designations in this instance do not reflect anthropological representation so much as African remembering and resilience. 
Taken together, these accounts of environment, development and displacement in Africa, divergent and important contemporary topics, share several features characteristic of the field in recent decades. They question anthropological concepts of society as bounded, argue against approaches that naturalize history or essentialize culture, and expose the ways in which these reified understandings of cultural difference are harnessed to political visions (Malkki 1995: 2, 14). These are Africanist anthropologists then who have chosen to take on the 'epistemic challenge' and have rejected 'localized' ethnography, but 'insist on its unique value in plumbing the nature and effects of large-scale social, economic, and political processes' (Comaroff \& Comaroff 2003: 156).

\section{Extraversion}

Beyond these major contributions to the anthropology of anthropology, and the discursive analysis of western epistemological categories, Africanist perspectives have also over the past several decades developed an anthropology that situates Africa within processes of extraversion, in Bayart's (2000) sense of the ways in which Africans actively participate in the processes that created the continent's dependent position within the global system. I will only touch on anthropological contributions to the study of religion and generation though many fields have been shaped by this perspective. The study of religion, in its many guises, I would argue, has emerged as a key research area in African anthropology. In relation to African traditional religion (cult possession movements and witchcraft) and the spread of the world religions, Christianity and Islam, the research output is remarkable. 
The anthropology of African traditional religion has witnessed a range of closely crafted analyses of spiritual worlds and ground-breaking interpretations of spirit possession cults. ${ }^{5}$ However, the analysis of witchcraft has become ubiquitous, and, as Ranger notes, the sheer bulk of published work on witchcraft seems problematically to validate the notion that 'Africa' and 'the occult' go together (Ranger 2007: 275). Witchcraft has long been indiscriminately used as a measure of primitiveness and a marker of otherness that freezes non-western subjects in a premodern time. Recent scholarship on the topic has explored the relationship between witchcraft and 'modern' social forms such as the state, the market and the media. Taking up Ardener's (1970) analysis of the economics of witchcraft in Cameroon, Geschiere's The Modernity of Witchcraft (1997) has proved a seminal text in understanding witchcraft not as an artefact of African tradition, but as the contemporary discourse on social and political change. Geschiere writes about the emergence of a small Maka elite from south-eastern Cameroon after 1945 who owed their preeminence to their modern education and to their links to the centralized Cameroon state. Recalling Marwick's (1970) notion of the 'index of social strain', Geschiere highlights the 'socially levelling' effects of accusations directed at this urban nouveaux riche and how accusations serve to delegitimize sources of wealth.

\footnotetext{
${ }^{5}$ On local cosmologies and 'moral' knowledge see, Bloch 1986; James 1988; Jackson 1989; Fardon 1991; Parkin 1991. On the analysis of spiritual knowledge, authority and identity, see McNaughton 1988; Dilley 2004; Kresse 2007; Marchand 2009. And on the analysis of spirit possession: (Stoller 1997) on the Nigerien hauka, (Olivier de Sardan 1984; Masquelier 2001) on Hausa bori, (Boddy 1989; Lewis et al. 1991) on $z \bar{a} r$ in Sudan, (Lan 1985) in relation to guerrilla warfare, (Sharp 1993) on health and well-being, and (Lambek 2002) on historical consciousness.
} 
These witchcraft discourses provide explanations not only of contingent misfortunes but of economic inequality, of new forms of individualism and the exploitation (or zombification) associated with the introduction of capitalist modes of production (Nash 1979; Taussig 1980).

In this reading then witchcraft accusations seem so widespread and to draw on such similar logics that they appear to capture a universal, 'a general uncertainty about modernity' (Ciekawy \& Geschiere 1998: 2), and hence witches are interpreted as 'modernity's prototypical malcontents' (Comaroff \& Comaroff 1993: xxviii-xxix). This theme has been examined in a range of regional and economic contexts (Moore \& Sanders 2001; Bond \& Ciekawy 2001; Meyer \& Pels 2003; West \& Sanders 2003), and has been developed in more recent works on secrecy and dissimulation in Sierra Leone (Ferme 2001), neoliberalism in Mozambique (West 2005), and spiritual uncertainty in the context of HIV/AIDS and democratic transition in South Africa (Ashforth 2000, 2005; Niehaus et al. 2001).

Witchcraft, it transpires, is a mode of African extraversion, a way of making sense of global economic and political change. Within this field, the study of African encounters with world religions directly addresses this issue of global connections. ${ }^{6}$ The interpretive challenge to an anthropology of religion that engages with worldhistorical processes is how to blend the narratives of world religions and endogenous

\footnotetext{
${ }^{6}$ The anthropology of Islam in Africa in recent decades has also focused on the tension between local and global, particular and universal, and urban scripturalist versus rural popularist traditions: see for example (Holy 1991; Launay 1992; Lambek 1993; Soares 2005).
} 
development in local societies. Contrasting perspectives on this question are captured in some of the most substantial anthropological scholarship emanating from the continent in the period under review: the Comaroffs' $(1991,1997)$ Of Revelation and Revolution and Peel's (2000) Religious Encounter and the Making of the Yoruba. In their study of the Tswana's 'long conversation' with Protestant missions during the nineteenth century in South Africa, the Comaroffs illustrate how conversion proceeded at two levels, the evangelical argument of 'images and message' and the hegemonic imposition of European cultural practices and technologies - literacy and fashion, agriculture and architecture, medicine and money. The latter, they argue, constituted a 'reform of the indigenous world', so that mission acted as a vector of colonial values and industrial capitalism at an everyday level, and colonial hegemony and Tswana subordination was naturalized by a 'colonization of the consciousness' (1991: 311). Hence, while they argue for a dialectical history of reciprocal determinations, ultimately it was the 'civilizing mission' of the evangelists which '... insinuated new forms of individualism, new regimes of value, new kinds of wealth, new means and relations of production, new religious practices' (Comaroff \& Comaroff 1997: 163) ${ }^{7}$

In contrast, in his study of the nineteenth-century encounters of missionaries in southwestern Nigeria, Peel argues that the local Yoruba population were active participants in the historical process of religious conversion and simultaneously accepted the new religion and utilized it to create something new - Yoruba Christianity. Developing Horton's theory of conversion as a 'cognitive and practical

\footnotetext{
${ }^{7}$ In its relation to subaltern agency, this study also builds on and provides an interesting counterpoint to Comaroff's (1985) study of Tshidi encounters with African independent churches.
} 
adjustment' Peel explains how a prior religious, ethical and cosmological ordering provided 'the conceptual bridgehead' (2000: 194) for subsequent mass Christian conversion. ${ }^{8}$ Arguing for the centrality of local religious change in the study of Christianity in Africa, he identifies the role of local society and culture in shaping the reception of mission and highlights how Yoruba ideas about power, status, cults and beliefs interpreted and accommodated Christian messages. In this reading then the emphasis within Yoruba religious narratives is not on the external forces of capitalism, colonialism, modernization and globalization but on the long span of African history, and religious movements with their own source and dynamics. As such Peel concludes that "the mission situation is shaped by those whom a mission seeks to convert as well as by the power behind the mission' (2000: 2).

For decades the study of youth was subsumed in anthropological reflections on gerontocratic social structures especially associated with East African age-set systems (Kurimoto \& Simonse 1998). In this context youth were defined in relation to life-cycle rituals, cohort initiation, and structural marginality. Understood as an historically constructed social category rather than as a predefined life-state, youth has more recently formed 'an especially sharp lens through which social forces are focused in Africa' (Durham 2000: 114). This interest has been sparked by a

\footnotetext{
${ }^{8}$ Reversing Horton's theory of conversion, Meyer's (1999) analysis of Christianity in Ghana shows how contact with the forces of modernity stimulated rather than diminished beliefs in local spirits. Her work also embraces the shift in the focus of study from the 1980s on African independent churches to Pentecostal churches more recently and how a strategy of extraversion is critical in explaining the mass appeal of Pentecostalism.
} 
generational contrast that has emerged between those who grew to adulthood in the first two decades of African Independence (1960-80) and their successors, a 'lost generation', who grew up at the end of the Cold War and under structural adjustment and neo-liberal reforms, and who see their 'youth' without work or wives as something which is at risk of becoming 'indefinitely prolonged' (Cruise O'Brien 1996: 58). Recent studies have tended to focus on the manifestations of this apparent crisis of social reproduction in terms of the mobilization of youth in the civil wars, notably Richards' (1996) study of the RUF in Sierra Leone, along with the concentration of youth displaced in refugee camps and on the streets of the continent's cities (Abbink \& Kessel 2004; Honwana \& Boeck 2005).

Beyond the relation between youth and conflict on the continent, however, youth has emerged as a productive focus for issues including livelihoods (Utas et al. 2006), gangs (Jensen 2008), education (Sharp 2002; Coe 2005; Straker 2007), childhood (Gottlieb 2004), and love and intimacy (Cole \& Thomas 2009; Cole 2010). Chernoff's (2003) Hustling is not Stealing, for instance, is an innovative verbatim oral history of a West African bar girl which provides an unique insight cutting across these issues of sex and survival in the African city. The contribution to the field from Africanist ethnographies of youth is ably demonstrated in two brief examples, Vigh's (2006) study of former combatants in Guinea-Bissau, Navigating Terrains of War, and Weiss's (2009) work with Tanzanian young men and popular culture in Street Dreams and Hip Hop Barbershops. Vigh's use of the concept of 'social navigation' in the volatile environment of an irregular militia revisits the anthropological issue of agency, and whether youth should be viewed as victims manipulated by powerful seniors, or as unrestrained perpetrators ('loose molecules'). Drawing on de Certeau, 
'social navigation' designates praxis 'attuned simultaneously to the immediate configurations of the social terrain and to its imagined [future] reconfigurations' (2006: 131). The barbers of Arusha, discussed in Weiss's study, navigate the iniquities of the neo-liberal economy through a subjectivity of tough 'invincibility', and employ hip hop sensibilities and consumer symbols to generate a sense of power. This 'thug realism' is a global fantasy of mobility and modernity generated by the very same forces that undermine their capacity to secure their own future (2009: 238).

\section{Conclusion}

Recent trajectories within Africanist anthropology, as in other regions, confirm this analysis of extraversion, particularly in relation to the themes of memory, modernity and mobility. Historical memory has become a direct object of analysis in, for example, the ethnography of how the West African slave trade is recalled in material culture (Ferme 2001), divination practices (Shaw 2002) and masquerade performance (Argenti 2007). The analysis of migration has drawn attention to the important roles of diasporic trading networks (MacGaffey \& Bazenguissa-Ganga 2000; Stoller 2002), transnational religious movements (Matory 2005), and to new modes of inclusion and exclusion, the 'dialectics of flow and closure', wrought by physical and social mobility in the era of globalization (Meyer \& Geschiere 1999; Geschiere 2009). Africanist anthropologists have also focused the ethnographic critique on the making of modern consumers (Burke 1996), modernist revolutions (Donham 1999), the modern nation-state (Askew 2002; Apter 2005), the modern city (De Boeck \& Plissart 2004), modern citizens (Wilson 2001; Englund 2006), modern ethnicities (Comaroff \& Comaroff 2009) and modern media (Larkin 2008). 
These are ethnographies of modernity in Africa which do not celebrate the triumph of modernist narratives but confirm a 'global disconnect', modernity's ‘decomposition' (Ferguson 2006: 192). Recent work has indeed attended to the normalization of crisis and uncertainty on the continent. These African expositions of existential uncertainty touch on 'structural distrust' in the context of HIV/AIDS (Whyte 1997; Hunter 2010) and a 'culture of crisis' in post-conflict contexts (Finnström 2008; Lubkemann 2008). Beneath the surface of this chaos or stagnation, however, it is also true that Africa is undergoing profound changes and that ' $\ldots$ the decomposition and recomposition of structures, institutions and identities in Africa is, therefore, one which needs to be researched more closely' (Olukoshi \& Laakso 1996: 77).

Anthropology in Africa is still alive to play its part. Where there is cause for optimism in the field is in the work of and recognition accorded African colleagues. The Council for the Development of Social Science Research in Africa's publication of African Anthropologies (Ntarangwi et al. 2006) heralded both a resurgence of the discipline at African universities (confirmed elsewhere (Nkwi 2007)), and also a strong argument in favour of dissolving the unhelpful 'pure/applied dichotomy', since many African anthropologists are increasingly stradding the two worlds of consultancy and the academy. And as anthropology is more careful than ever not to essentialize or exoticize the continent, so anthropologists are increasingly able to challenge the journalistic impressions of a continent beset by crisis and failure not only with ethnographic counter examples, but by engaging with the category of 'Africa' and its place in the world (Ferguson 2006). 
Retroversion, introversion and extraversion are not mutually exclusive categories by which we can understand the recent history of Africanist anthropology. Nor are they discrete stages through which that history has passed. Nevertheless, since the 1980s African anthropology has challenged its past, interrogated the categories through which it knows the continent, and has illuminated those histories and issues through which Africa has been entangled with the rest of the world. Whether Africa is more important to anthropology than anthropology is to Africa these days is moot - the relationship on both axes waxes and wanes. But perhaps the relative strength of the relationship between anthropology and Africa is not the issue; both are mutually implicated and mutually dependent. 
Acknowledgements

My sincere thanks to William Beinart, Richard Fardon, Henrik Vigh, JDY Peel, Staffan Löfving, Ana Margarida Sousa Santos and Julie Archambault for their help and advice.

\section{References}

Abbink, J. \& I. v. Kessel (eds) (2004) Vanguard or Vandals: Youth, Politics and Conflict in Africa, Leiden: Brill.

Apter, A. (1999) 'Africa, Empire, and Anthropology: A Philological Exploration of Anthropology's Heart of Darkness', Annual Review of Anthropology 28: 57798.

Apter, A. H. (2005) The Pan-African nation: oil and the spectacle of culture in Nigeria. Chicago: University of Chicago Press.

Ardener, E. (1970) 'Witchcraft, Economics and the Continuity of Belief', in Douglas, M. (ed) Witchcraft Confessions and Accusations. London: Tavistock.

Argenti, N. (2007) The intestines of the state: youth, violence, and belated histories in the Cameroon grassfields. Chicago: University of Chicago Press.

Asad, T. (ed) (1973) Anthropology and the Colonial Encounter. London: Ithaca Press.

Ashforth, A. (2000) Madumo, a man bewitched. Chicago: University of Chicago Press.

— (2005) Witchcraft, violence, and democracy in South Africa. Chicago: University of Chicago Press.

Askew, K. M. (2002) Performing the nation: Swahili music and cultural politics in 
Tanzania. Chicago: University of Chicago Press.

Bank, L. J. (2011) Home spaces, street styles: contesting power and identity in a South African city. London: Pluto.

Barnard, A. (2001) 'Africa and the Anthropologist', Africa 71 (1): 162-70.

— (2007) Anthropology and the bushman. Oxford: Berg.

Bates, R. H., V. Y. Mudimbe \& J. F. O'Barr (eds) (1993) Africa and the disciplines: the contributions of research in Africa to the social sciences and humanities, Chicago: University of Chicago Press.

Bayart, J. F. (2000) 'Africa in the world: A history of extraversion', African Affairs 99 (395): 217-67.

Bloch, M. (1986) From Blessing to Violence: History and Ideology in the Circumcision Ritual of the Merina of Madagascar. Cambridge: Cambridge University Press.

Boddy, J. (1989) Wombs and alien spirits: women, men, and the zar cult in northern Sudan. Madison; London: University of Wisconsin Press.

Bond, G. C. \& D. Ciekawy (eds) (2001) Witchcraft Dialogues: Anthropological and Philosophical Exchanges Athens: Ohio University Press.

Burke, T. (1996) Lifebuoy men, lux women: commodification, consumption, and cleanliness in modern Zimbabwe. Durham: Duke University Press.

Chernoff, J. M. (2003) Hustling is not stealing: stories of an African bar girl. Chicago: University of Chicago Press.

Ciekawy, D. \& P. Geschiere (1998) 'Containing withcraft: conflicting scenarios in postcolonial Africa', African Studies Review 41 (3): 1-14.

Coe, C. (2005) Dilemmas of culture in African schools: youth, nationalism, and the transformation of knowledge. Chicago: University of Chicago Press. 
Cole, J. (2010) Sex and salvation: imagining the future in Madagascar. Chicago: University of Chicago Press.

Cole, J. \& L. M. Thomas (eds) (2009) Love in Africa. Chicago: University of Chicago Press.

Comaroff, J. (1985) Body of Power, Spirit of Resistance. The culture and history of a South African People. Chicago: University of Chicago Press.

Comaroff, J. \& J. L. Comaroff (2003) 'Ethnography on an Awkward Scale:

Postcolonial Anthropology and the Violence of Abstraction', Ethnography 4 (2): 147-79.

- (1991) Of revelation and revolution: Christianity, colonialism, and consciousness in South Africa. Chicago: University of Chicago Press.

— (1997) Of revelation and revolution: The dialectics of modernity on a South African frontier. Chicago: University of Chicago Press.

Comaroff, J. L. \& J. Comaroff (2009) Ethnicity, Inc. Chicago: University of Chicago Press.

Comaroff, J. \& J. L. Comaroff (eds) (1993) Modernity and its Malcontents, Ritual and Power in Postcolonial Africa, Chicago: University of Chicago Press.

Crehan, K. A. F. (1997) The fractured community: landscapes of power and gender in rural Zambia. Berkeley: University of California Press.

Cruise O’Brien, D. B. (1996) 'A Lost Generation? Youth identity and state decay in West Africa', in Werbner, R. \& T. Ranger (eds.) Postcolonial Identities in Africa. London and New York: Zed Books.

De Boeck, F. \& M. F. Plissart (2004) Kinshasa: Tales of the Invisible City. Ludion: Royal Museum for Central Africa.

Dilley, R. (2004) Islamic and caste knowledge practices among Haalpulaar'en in 
Senegal: between mosque and termite mound. Edinburgh: Edinburgh University Press.

Donham, D. L. (1999) Marxist modern: an ethnographic history of the Ethiopian revolution. Berkeley: University of California Press.

Durham, D. (2000) 'Youth and the Social Imagination in Africa: Introduction to Parts 1 and 2', Anthropological Quarterly 73 (3): 113-20.

Englund, H. (2006) Prisoners of freedom: human rights and the African poor. Berkeley: University of California Press.

Evens, T. M. S. \& D. Handelman (2006) 'Introduction: The Ethnographic Praxis of the Theory of Practice', in Evens, T.M.S. \& D. Handelman (eds.) The Manchester School: practice and ethnographic praxis in anthropology. New York: Berghahn.

Fairhead, J. \& M. Leach (1996) Misreading the African landscape: society and ecology in a forest-savanna mosaic. Cambridge: Cambridge University Press.

Fardon, R. (1991) Between God, the Dead and the Wild. Edinburgh: Edinburgh University Press.

— (ed) (1990) Localizing Strategies: Regional Traditions of Ethnographic Writing, Edinburgh and Smith: Scottish Academic Press.

Ferguson, J. (1990) The Anti-Politics Machine. "Development”, Depoliticization and Bureaucratic Power in Lesotho. Minneapolis: University of Minnesota Press.

— (1997) 'Anthropology and its evil twin: development in the constitution of a discipline', in Cooper, F. \& R. Packard (eds.) International Development and the Social Sciences. Berkeley: University of California Press.

- (1999) Expectations of Modernity: Myths and Meanings of Urban Life on the Zambian Copperbelt. Berkeley: University of California Press. 
— (2006) Global shadows: Africa in the neoliberal world order. Durham: Duke University Press.

Ferme, M. C. (2001) The underneath of things: violence, history, and the everyday in Sierra Leone. Berkeley: University of California Press.

Finnström, S. (2008) Living with bad surroundings: war, history, and everyday moments in northern Uganda. Durham: Duke University Press.

Foucault, M. (1977) Discipline and Punish: The Birth of the Prison. London: Penguin Books.

Geschiere, P. (1997) The modernity of witchcraft: politics and the occult in postcolonial Africa. Charlottesville: University of Virginia.

— (2009) The perils of belonging: autochthony, citizenship, and exclusion in Africa and Europe. Chicago: University of Chicago Press.

Goody, J. (1995) The expansive moment: the rise of social anthropology in Britain and Africa, 1918-1970. Cambridge: Cambridge University Press.

Gordon, R. (1990) 'Early social anthropology in South Africa', African Studies 49 (1): $15-48$.

Gordon, R. J. \& A. D. Spiegel (1993) 'Southern Africa Revisited', Annual Review of Anthropology 22 (1): 83-105.

Gottlieb, A. (2004) The afterlife is where we come from: the culture of infancy in West Africa. Chicago: University of Chicago Press.

Guyer, J. (1999) 'Anthropology: The Study of Social and Cultural Originality', African Sociological Review 3 (2): 30-53.

Guyer, J. I. (2004) 'Anthropology in Area Studies', Annual Review of Anthropology 33 (1): 499-523.

Hammond-Tooke, W. D. (1997) Imperfect Interpreters: South Africa's 
anthropologists, 1920-1990. Johannesburg: Witwatersrand University Press.

Hansen, K. T. (1991) 'After Copper Town - the Past in the Present in Urban Zambia', Journal of Anthropological Research 47 (4): 441-56.

Hansen, K. T. (2000) Salaula: the world of secondhand clothing and Zambia. Chicago: University of Chicago Press.

Hart, J. K. (1985) 'The Social Anthropology of West Africa', Annual Review of Anthropology 14: 243-72.

Herzfeld, M. (2001) Anthropology: theoretical practice in culture and society. Malden, Mass.: Blackwell Publishers.

Holy, L. (1991) Religion and custom in a Muslim society: the Berti of Sudan. Cambridge: Cambridge University Press.

Honwana, A. \& F. d. Boeck (eds) (2005) Makers and Breakers Children and Youth in Postcolonial Africa, Oxford: James Currey.

Hunter, M. (2010) Love in the time of AIDS: inequality, gender, and rights in South Africa. Bloomington: Indiana University Press.

Hutchinson, S. E. (1996) Nuer dilemmas: coping with money, war, and the state. Berkeley: University of California Press.

Jackson, M. (1989) Paths toward a clearing: radical empiricism and ethnographic inquiry. Bloomington: Indiana U.P.

James, W. (1988) The listening ebony: moral knowledge, religion, and power among the Uduk of Sudan. Oxford: Clarendon Press.

- (1990) 'Kings, Commoners, and the Ethnographic Imagination in Sudan and Ethiopia', in Fardon, R. (ed) Localizing Strategies: Regional Traditions of Ethnographic Writing. Edinburgh and Smith: Scottish Academic Press.

Jensen, S. (2008) Gangs, politics \& dignity in Cape Town. University of Chicago 
Press.

Keita, L. (1989) 'Research Discipline in the African Context: A Revised Paradigm', Quest 3 (1): 3-19.

Kresse, K. (2007) Philosophising in Mombasa : knowledge, Islam and intellectual practice on the Swahili coast. Edinburgh: Edinburgh University Press.

Kuklick, H. (1991) The savage within: the social history of British anthropology, 1885-1945. Cambridge: Cambridge University Press.

Kuper, A. (1999) 'South African Anthropology. An inside Job’, Paideuma 45: 83-101. Kurimoto, E. \& S. Simonse (eds) (1998) Conflict, age and power in North East Africa: age systems in transition, Oxford: James Currey.

Lambek, M. (1993) Knowledge and practice in Mayotte: local discourses of Islam, sorcery and spirit possession. Toronto: University of Toronto Press.

— (2002) The weight of the past: living with history in Mahajanga, Madagascar. New York: Palgrave Macmillan.

Lan, D. (1985) Guns and Rain: Guerrillas and Spirit Mediums in Zimbabwe. London: James Currey.

Larkin, B. (2008) Signal and noise: media, infrastructure, and urban culture in Nigeria. Durham: Duke University Press.

Launay, R. (1992) Beyond the stream: Islam and society in a West African town. Berkeley: University of California Press.

Leach, M. \& R. Mearns (eds) (1996) The Lie of the Land: Challenging Received Wisdom on the African Environment. London: James Currey.

Lee, R. B. \& M. Guenther (1993) 'Problems in Kalahari Historical Ethnography and the Tolerance of Error', History in Africa 20: 185-235.

Lewis, I. M., A. Safi \& S. Hurreiz (1991) Women's medicine: the Zar-Bori cult in 
African and beyond. Edinburgh: Edinburgh University Press.

Lubkemann, S. C. (2008) Culture in chaos: an anthropology of the social condition in war. Chicago: University of Chicago Press.

MacGaffey, J. \& R. Bazenguissa-Ganga (2000) Congo-Paris: transnational traders on the margins of the law. Oxford: James Currey.

Mafeje, A. (1971) 'The Ideology of Tribalism', Journal of Modern African Studies 9 (2): 253-61.

— (1997) "Who are the Makers and Objects of Anthropology? A Critical Comment on Sally Falk Moore's “Anthropology and Africa”, African Sociological Review 1 (1): 1-15.

— (1998a) 'Anthropology and Independent Africans: Suicide or End of an Era?', African Sociological Review 2 (1): 1-43.

— (1998b) 'Debates \& Rejoinders: Conversations and Confrontations with my Reviewers', African Sociological Review 2 (2): 95-107.

- (2001) Anthropology in Post-Independence Africa: End of an Era and the problem of self-redefinition. Nairobi: Heinrich Böll Foundation.

Magubane, B. (1971) 'A Critical Look at Indices Used in the Study of Social Change in Colonial Africa', Current Anthropology 12 (4/5): 419-45.

— (1973) 'The "Xhosa" in Town, Revisited Urban Social Anthropology: A Failure of Method and Theory', American Anthropologist 75 (5): 1701-15.

Magubane, B. \& J. C. Faris (1985) 'On the political relevance of anthropology', Dialectical Anthropology 9 (1): 91-104.

Malkki, L. H. (1995) Purity and exile: violence, memory, and national cosmology among Hutu refugees in Tanzania. Chicago: University of Chicago Press.

Marchand, T. H. J. (2009) The masons of Djenné. Bloomington: Indiana University 
Press.

Marcus, G. E. \& M. M. J. Fischer (1999) Anthropology as cultural critique: an experimental moment in the human sciences. Chicago: University of Chicago Press.

Marwick, M. (1970) 'Sorcery as a Social Strain Gauge', in Marwick, M. (ed) Witchcraft and sorcery: selected readings. London: Penguin.

Masquelier, A. M. (2001) Prayer has spoiled everything: possession, power, and identity in an Islamic town of Niger. Durham: Duke University Press.

Matory, J. L. (2005) Black Atlantic religion: tradition, transnationalism, and matriarchy in the Afro-Brazilian Candomblé. Princeton: Princeton University Press.

Mayer, P. \& with I. Mayer (1961) Townsmen or Tribesmen: Conservatism and the Process of Urbanization in a South African City. Cape Town: Oxford University Press.

McNaughton, P. (1988) The Mande blacksmiths: knowledge, power and art in West Africa. Bloomington: Indiana University Press.

Meyer, B. (1999) Translating the Devil: religion and modernity among the Ewe in Ghana. Edinburgh: Edinburgh University Press.

Meyer, B. \& P. Geschiere (eds) (1999) Globalization and identity: dialectics of flow and closure, Oxford: Blackwell.

Meyer, B. \& P. Pels (eds) (2003) Magic and modernity: interfaces of revelation and concealment, Stanford: Stanford University Press.

Moore, H. L. \& T. Sanders (eds) (2001) Magical interpretations, material realities: modernity, witchcraft, and the occult in postcolonial Africa, London: Routledge. 
Moore, H. L. \& M. Vaughan (1994) Cutting down trees: gender, nutrition, and agricultural change in the Northern Province of Zambia, 1890-1990. Portsmouth: Heinemann.

Moore, S. F. (1994) Anthropology and Africa: changing perspectives on a changing scene. Charlottesville: University of Virginia.

Mudimbe, V. Y. (1985) 'African Gnosis Philosophy and the Order of Knowledge: An Introduction', African Studies Review 28 (2/3): 149-233.

- (1988) The invention of Africa: gnosis, philosophy, and the order of knowledge. Bloomington: Indiana University Press.

Nash, J. (1979) We eat the mines and the mines eat us: dependency and exploitation in Bolivian Tin Mines. New York: Columbia University Press.

Niehaus, I. A., E. Mohlala \& K. Shokane (2001) Witchcraft, power, and politics: exploring the occult in the South African lowveld. London: Pluto Press.

Nkwi, P. N. (2007) 'Editorial: Resurgence of Anthropology at African Universities’, African Anthropology 14 (v-vii).

Ntarangwi, M., D. Mills \& M. H. M. Babiker (eds) (2006) African anthropologies: history, critique, and practice, London and New York: Zed Books.

Olivier de Sardan, J.-P. (1984) Les sociétés Songhay-Zarma, Niger-Mali: chefs, guerriers, esclaves, paysans. Paris: Karthala.

Olukoshi, A. O. \& L. Laakso (1996) Challenges to the Nation-State in Africa. Uppsala: Nordiskaafrikaininstitut.

Owusu, M. (1978) 'Ethnography of Africa: The Usefulness of the Useless', American Anthropologist 80 (2): 310-34.

Parkin, D. (1990) 'Eastern Africa: the View from the Office and the Voice from the Field', in Fardon, R. (ed) Localizing Strategies: Regional Traditions of 
Ethnographic Writing. Edinburgh: Scottish Academic Press.

Parkin, D. J. (1991) Sacred void: spatial images of work and ritual among the Giriama of Kenya. Cambridge: Cambridge University Press.

Peel, J. D. Y. (2000) Religious Encounter and the Making of the Yoruba. Bloomington: Indiana University Press.

Pels, P. (1997) 'The Anthropology of Colonialism: Culture, History, and the Emergence of Western Governmentality', Annual Review of Anthropology 26: $163-83$.

Piot, C. (1999) Remotely Global: Village Modernity in West Africa. Chicago: University of Chicago Press.

Ranger, T. (2007) 'Scotland Yard in the Bush: Medicine Murders, Child Witches and the Construction of the Occult: A Literature Review', Africa 77 (2): 272-83.

Richards, A. I. (1939) Land, labour and diet in northern Rhodesia: an economic study of the Bemba tribe. Oxford: Oxford University Press.

Richards, P. (1985) Indigenous Agricultural Revolution: Ecology and Food production in West Africa. London: Hutchinson.

— (1996) Fighting for the Rainforest: war, youth and resources in Sierra Leone. London: James Currey.

Rigby, P. (1996) African images: racism and the end of anthropology. London: Berg. Schumaker, L. (2001) Africanizing anthropology: fieldwork, networks, and the making of cultural knowledge in central Africa. Durham: Duke University Press.

Sharp, J. S. (1981) 'The Roots and Development of Volkekunde in South Africa', Journal of Southern African Studies 8 (1): 16-36.

Sharp, L. A. (1993) The possessed and the dispossessed: spirits, identity, and power 
in a Madagascar migrant town. Berkeley: University of California Press.

- (2002) The sacrificed generation: youth, history, and the colonized mind in Madagascar. Berkeley: University of California Press.

Shaw, R. (2002) Memories of the slave trade: ritual and the historical imagination in Sierra Leone. Chicago: University of Chicago Press.

Soares, B. F. (2005) Islam and the prayer economy: history and authority in a Malian town. Edinburgh: Edinburgh University Press.

Southall, A. (1983) 'The Contribution of Anthropology to African Studies', African Studies Review 26 (3/4): 63-76.

Stoller, P. (1997) Embodying Colonial Memories: Spirit Possession, Power and the Hauka in West Africa. New York: Routledge.

— (2002) Money has no smell: the Africanization of New York City. Chicago: University of Chicago Press.

Straker, J. (2007) 'Youth, globalisation, and millennial reflection in a Guinean forest town', The Journal of Modern African Studies 45 (2): 299-319.

Taussig, M. (1980) The devil and commodity fetishism in South America. Chapel Hill: University of North Carolina Press.

Tilley, H. \& R. J. Gordon (eds) (2007) Ordering Africa: anthropology, European imperialism and the politics of knowledge, Manchester: Manchester University Press.

Tonkin, E. (1990) 'West African Ethnographic Traditions', in Fardon, R. (ed) Localizing Strategies: Regional Traditions of Ethnographic Writing. Edinburgh: Scottish Academic Press.

Utas, M., H. Vigh \& C. Christiansen (eds) (2006) Navigating Youth Generating Adulthood: social becoming in an African context, Uppsala: Nordiska 
Afrikainstitutet.

Vigh, H. (2006) Navigating terrains of war: youth and soldiering in Guinea-Bissau. New York: Berghahn Books.

Weiss, B. (2009) Street dreams and hip hop barbershops: global fantasy in urban Tanzania. Bloomington: Indiana University Press.

Werbner, R. P. (1984) 'The Manchester School in South-Central Africa', Annual Review of Anthropology 13: 157-85.

— (1990) 'South-Central Africa: The Manchester School and After', in Fardon, R. (ed) Localizing Strategies: Regional Traditions of Ethnographic Writing. Edinburgh: Scottish Academic Press.

West, H. G. (2005) Kupilikula: governance and the invisible realm in Mozambique. Chicago: University of Chicago Press.

West, H. G. \& T. Sanders (2003) Transparency and conspiracy: ethnographies of suspicion in the new world order. Durham: Duke University Press.

Whyte, S. R. (1997) Questioning misfortune: the pragmatics of uncertainty in Eastern Uganda. Cambridge: Cambridge University Press.

Wilmsen, E. N. (1989) Land filled with flies: a political economy of the Kalahari. Chicago: University of Chicago Press.

Wilson, R. (2001) The politics of truth and reconciliation in South Africa: legitimizing the post-apartheid state. Cambridge: Cambridge University Press.

Wolf, E. R. (1982) Europe and the people without history. Berkeley: University of California Press. 